стеатозе равен 13,6 лет, а при стеатогепатите 13,5 лет, что не имеет достоверного различия.

1. Лазебник Л.Б., Радченко В.Г., Голованова Е.В. и др. Неалкогольная жировая болезнь печени: клиника, диагностика, лечение (рекомендации для терапевтов, 2-я версия). Экспериментальная и клиническая гастроэнтерология, 2017, № 2 (138), с. 22-37.

2. Ивашкин В.Т., Ивашкина Н.Ю., Баранская Е.К. и др. Алкогольная болезнь печени. Рациональная фармакотерапия заболеваний органов пищеварения. Руководство для практикующих врачей 2-е издание. - М.: «Литтерра», 2011.-844c.

3. Kleiner DE, Brunt EM, Van Natta $\mathrm{M}$ et al. Design and validation of a histological scoring system for nonalcoholic fatty liver disease. Hepatology, 2005, vol. 41, pp. 1313-1321.

4. Bellentani S., Marino M. Epidemiology and natural history of non-alcoholic fatty liver disease (NAFLD). Annals of Hepatology. 2009, vol. 8, no. 1, pp. 4-8.

5. Vernon G., Baranova A., Younossi Z. M. Systematic review: the epidemiology and natural history of nonalcoholic fatty liver disease and non-alcoholic steatohepatitis in adults. Alimentary Pharmacology and Therapeutics. 2011, vol. 34, no. 3, pp. 274-285.

6. McCullough AJ. The clinical features, diagnosis and natural history of nonalcoholic fatty liver disease. Clin Liver Dis. 2004, no. 8, pp. 521-533.

7. Драпкина О.М., Смирин В.И., Ивашкин В.Т. Патогенез, лечение, эпидемиология НАЖБП - что нового? Эпидемиология НАЖБП в России. Русский медицинский журнал, 2011, № 28, с. 1717-1721

8. Ивашкин В.Т., Драпкина О.М., Маев И.В. и др. Распространенность неалкогольной жировой болезни печени у пациентов амбулаторно-поликлинической практики в Российской Федерации: результаты исследования DIREG 2. Гепатология, 2015, №6, с. 31-41.

\title{
Afanasyev S.O., Shiryaev O.U., Makhortova I.S. Assessment of Social Anxiety and Eating Disorders Prevalence in Voronezh State Medical University Students
}

Voronezh State Medical University, clinic “LION-MED”

(Russia, Voronezh)

doi: $10.18411 /$ scienceconf-03-2021-12

idsp: scienceconf-03-2021-12

Key words: social anxiety, eating disorders, anorexia nervosa, bulimia nervosa, medical students

Introduction Prevalence of anxiety and depression has increased worldwide in last decades [1]. Bandelow B, Michaelis S (2015) state that $33.7 \%$ of the population suffer from an anxiety disorder during lifetime [2].

The cost of treating anxiety is significant for health-care system. According to a study conducted by Wallace K, Zhao X, Misra R in 2018, for adults suffering from both depression and anxiety 28,832 dollars per person are spent every year, followed by patients with depression (19,648 dollars) or anxiety (16,990 dollars) [3].

Prevalence of mental health problems in medical students is constantly growing and exceeds the prevalence of mental health problems in students of other specialties, which can lead to serious consequences for students themselves and their future patients [4]. The metaanalysis conducted by Zeng W, Chen R, Wang X et al (2019) included ten cross-sectional studies involving 30,817 Chinese medical students. Prevalence of depression, anxiety, suicidal thoughts, and eating disorders (ED) was $29 \%, 21 \%, 11 \%$, and $2 \%$, respectively [4].

According to other meta-analysis social anxiety disorder (SAD) is one of the most common comorbid diseases in ED with a prevalence of SAD from 16 to $88.2 \%$ in anorexia nervosa and $17-67.8 \%$ in bulimia nervosa, while the lifetime prevalence of SAD in the population without ED is just 12\% [5]. SD and ED are associated with an increased risk for life quality declining of University students which may result to distorted psychological and social adaptation [6]. SD in students may also lead to alcohol and drug addiction. [8]. 
University education itself often leads SD and ED. Manifestation of other psychiatric disorders is also associated with this period of life [6,7].

Objective: Assessment of social anxiety and eating disorders prevalence in students of Voronezh State Medical University him. N.N. Burdenko.

Methods The included 1100 participants from first to sixth years of education in Voronezh State Medical University. The prevalence of anxiety and eating disorders was estimated with Liebowitz social anxiety scale (LSAS) and The Dutch Eating Behavior Questionnaire (DEBQ)

\section{Results}

According to data analysis, $46 \%$ of students didn't reveal any level of social anxiety. Scores of low social anxiety level were found in $30 \%$, moderate level - in 16\%, marked level - in $6 \%$. High level of SAD was revealed only in $2 \%$.

Among participants of first year $(n=150) 38 \%$ didn't have any features of social anxiety. Low social anxiety level was diagnosed in $30 \%$, moderate level - in $22 \%$, marked level - in 6\%, and high level - in $4 \%$.

Among third year students ( $\mathrm{n}=150), 42 \%$ didn't have any significant level of social anxiety. Low social anxiety level were revealed in $32 \%$, moderate level - in $16 \%$, marked level - in $8 \%$, and high level - in $2 \%$.

Finally, among fifth year students $(n=150), 56 \%$ didn't have any significant level of social anxiety. Symptoms of low social anxiety level were revealed in $30 \%$, moderate level in $10 \%$, marked level - in $4 \%$. No high level anxiety features were found in this group.

Table

The average DEBQ score of participants

\begin{tabular}{|c|c|c|c|}
\hline $\begin{array}{c}\text { Year of } \\
\text { education }\end{array}$ & restrained eating & emotional eating & external eating \\
\hline 1 & $2,02 \pm 0,01$ & $1,65 \pm 0,01$ & $2,19 \pm 0,02$ \\
\hline 2 & $2,31 \pm 0,02$ & $1,64 \pm 0,01$ & $2,11 \pm 0,01$ \\
\hline 3 & $2,15 \pm 0,01$ & $1,7 \pm 0,01$ & $2,27 \pm 0,01$ \\
\hline 4 & $2,01 \pm 0,01$ & $1,69 \pm 0,01$ & $2,26 \pm 0,02$ \\
\hline 5 & $2,49 \pm 0,015$ & $2,05 \pm 0,01$ & $2,29 \pm 0,01$ \\
\hline 6 & $2,20 \pm 0,01$ & $1,79 \pm 0,01$ & $2,29 \pm 0,02$ \\
\hline
\end{tabular}

\section{Conclusion}

1) Features of social anxiety and eating disorders were revealed in more than half of participants $(54 \%)$.

2) Most students had low and moderate levels of social anxiety.

3) Anxiety was lower in fifth year students.

4) High level of social anxiety was revealed in first and third year students.

5) More research in social anxiety and eating disorders in medical University students is required.

$$
* * *
$$

1. Stein DJ, Lim CCW, Roest AM, de Jonge P, Aguilar-Gaxiola S, Al-Hamzawi A, Alonso J, Benjet C, Bromet EJ, Bruffaerts R, de Girolamo G, Florescu S, Gureje O, Haro JM, Harris MG, He Y, Hinkov H, Horiguchi I, Hu C, Karam A, Karam EG, Lee S, Lepine JP, Navarro-Mateu F, Pennell BE, Piazza M, Posada-Villa J, Ten Have M, Torres Y, Viana MC, Wojtyniak B, Xavier M, Kessler RC, Scott KM; WHO World Mental Health Survey Collaborators. The cross-national epidemiology of social anxiety disorder: Data from the World Mental Health Survey Initiative. BMC Med. 2017 Jul 31;15(1):143. doi: 10.1186/s12916-017-0889-2. PMID: 28756776; PMCID: PMC5535284.

2. Bandelow B, Michaelis S. Epidemiology of anxiety disorders in the 21st century. Dialogues Clin Neurosci. 2015 Sep;17(3):327-35. PMID: 26487813; PMCID: PMC4610617.

3. Wallace K, Zhao X, Misra R, Sambamoorthi U. The Humanistic and Economic Burden Associated with Anxiety and Depression among Adults with Comorbid Diabetes and Hypertension. J Diabetes Res. 2018 Oct 24;2018:4842520. doi: 10.1155/2018/4842520. PMID: 30474044; PMCID: PMC6220385. 
4. Zeng W, Chen R, Wang X, Zhang Q, Deng W. Prevalence of mental health problems among medical students in China: A meta-analysis. Medicine (Baltimore). 2019 May;98(18):e15337. doi: 10.1097/MD.0000000000015337. PMID: 31045774; PMCID: PMC6504335.

5. Kerr-Gaffney J, Harrison A, Tchanturia K. Social anxiety in the eating disorders: a systematic review and meta-analysis. Psychol Med. 2018 Nov;48(15):2477-2491. doi: 10.1017/S0033291718000752. Epub 2018 Apr 10. PMID: 29631640.

6. Shiryaev O.U. Relationship between family and personal perfectionism of students: gender aspects / O.U. Shiryaev, M.V. Larskikh // Proceedings Of Voronezh State University. Series: Problems Of Higher Education. 2016. - № 2. - P. 12-15.

7. Krasnova V.V. Holmogorova A.B. Social anxiety and its connection with emotional inadaptation, stress level and interpersonal relationships quality in students // Voprosy Psychologii. - 2011. №3. - P. 49-58.

8. Esaulenko I.E. Preventing psychotraumatic stress disorders, adaptation disorder and suicide in young people / I.E. Esaulenko, E.A. Semyonova // System analysis and management in biomedical systems. 2014.-T. 13. No. 2. - P. 453-462.

\section{Mamontova A. \\ Markers of skin aging and quality of life indicators for women with menopausal syndrome}

State Budgetary Health Instution "Regional Clinical Hospital No 3", Ministry of Health of the Russian Federation (Russia, Chelyabinsk)

doi: $10.18411 /$ scienceconf-03-2021-13

idsp: scienceconf-03-2021-13

Introduction. Despite the fact that all organs and systems are involved in the aging process, the most significant for women are the visual manifestations of aging, primarily skin changes, in particular the facial skin. This fact is confirmed by the high popularity of cosmetology services. On the one hand, it is known that various skin diseases negatively affect the quality of life (QOL) of a person [1,2].It has been established that QOL worsens if the patient has diseases that are manifested by skin defects [3]. On the other hand, aging of the body and associated changes are the main factor that leads to a decrease in QOL.

Aim.The aim of this study is to identify the relationship between markers of skin aging and QOL in women with menopausal syndrome (MS).

Materials and methods. We examined 36 women in the period of menopausal transition (MT) $(n=12)$ and postmenopause $(\mathrm{PM})(\mathrm{n}=24)$, who applied for a specialized appointment on the problems of menopause in clinics of Regional Clinical Hospital No 3 and Regional Clinical Hospital No 1.

All women underwent anamnesis collection and determination of the modified menopausal index (MMI) (Kupperman H. et al. 1959, modified by Uvarova E.V. 1983) [4].

After the initial examination by a gynecologist, the patients with MS were referred to a cosmetologist who performed computer mapping of the facial skin (CMFS), using a digital video camera "AramoSG" with the skinXPpro program. Facial skin examination included: tests for moisture and elasticity, oiliness (in the T- and U-zones of the face), determination of smoothness / roughness (skin relief), pore sizes, pigmentation, skin sensitivity and test of wrinkle depth and width. Patients were also asked to fill out a special Women's Health Questionnaire (WHQ) [5,6] (by Dr. Myra Hunter, Department of Psychology Adamson, Center ST Thomas Hospital, Lambeth Palace Road, London, UK), which psychometric properties in Russian-speaking population was studied by Russian authors [7]. The questionnaire consists of 37 questions, which are combined into 9 scales [5,6,7]: Depression (DEP), Somatic symptoms (SOM), Memory / concentration (MEM), Vasomotor symptoms (VAS), Anxiety / fears (ANX), Sexual problems (SEX), Sleep (SLE), Menstrual symptoms (MEN), Attractiveness (ATT). Each scale has a dimension from 0 to 1 point, the closer the value is to 0 , the better the QOL of the respondent [7]. Statistical processing was performed 